\title{
Secretory azoospermia or non-obstructive azoospermia?
}

\author{
J.M. Rigot \\ Service d'Andrologie - CHRU de Lille, France
}

\begin{abstract}
In the non-obstructive azoospermia versus the secretory azoospermia it is first necessary to have a clear assessment and definition and then takes care of the patient before the surgical sampling taking into account the age of the woman and in fine try to optimize the residual spermatogenesis. Biopsy seems to be the "gold standard" in non-obstructive azoospermia. The mean level of retrieval (extracted) spermatozoa is of $50 \%$, with $20 \%$ of pregnancy/cycle and $30 \%$ of delivery/couple with a better success for frozen sperm samples.
\end{abstract}

Key words: human male infertility, non-obtstructive azoospermia, secretory azoospermia, biopsy, spermatozoa, fertilization

\section{Introduction}

The word "non-obstructive azoospermia" has been suggested for the first time in 1996 by Devroey to differentiate these patients with those suffering of obstructive azoospermia [3]. In fact that definition is linked to the surgical retrieval of spermatozoa for an ICSI and therefore it is related to the management of the sample in the laboratory. Indeed that term has nothing to do with the histological definition of secretory azoospermia. Thus the levels of sperm extraction are very different as reported recently by Harris in 2008 [7]: $89 \%$ of extraction for hypospermatogenesis, $63 \%$ for maturation arrest, and $13 \%$ for the Sertoli cell only syndrome $[9,12]$.

\section{Results from our experience}

Between 1995 and 2007, at the CHRU of Lille, 863 samplings of which 752 from testes $(87 \%)$ have been performed. The mean age of the patients was 33.1 years (20-59) with a mean second surgery of $1.4 \%$. From this surgery the level of positive extraction was of $64 \%$. In the table 1 when FSH was increased FSH, the level of extraction was of $47 \%$ but taking into account only the results from the anatomopathology it is clear that the levels of extraction are different with a record of $58 \%$ for abnormal spermatogenesis.

When we have compared the patients with secretory azoospermia, and increased FSH levels, with those

Correspondence: JM Rigot, Service d'Andrologie - CHRU de Lille-59000, France; tel. (...), fax (...),

e-mail: jm-rigot@chru-lille.fr with normal FSH but associated with either germ cell aplasia or arrest in germ cell maturation, the levels of sperm retrieval was quite identical. Conversely in patients with hypospermatogenesis the percentage of extraction was $95 \%$. Thus, considering all patients with non-obstructive azoospermia either together or not related to the FSH levels, the amount of extracted sperm could be greatly modified.

Consequently for patients with non-obstructive azoospermia we suggest to take into account the following criteria: increased FSH level and/or germ cell aplasia stop in germ cell maturation, seminiferous tubules atrophy except the patients with congenital absence of vas deferens, ejaculatory dysfunction or excretory azoospermia (Table 2). These considerations are thus important to evaluate the activity of an AMP center, especially it is recommended to clearly define the total number of patients with azoospermia either visited or not by the physician, the method used to classify the patients before sperm retrieval before the analysis of results.

In front of a non-obstrcutive azoospermia a very careful clinical assessment should be therefore realized with special emphasis to previous history i.e age, tobacco, alcohol and obesity are clearly unfavourable factors [2]. The known past history of the patient is significantly in favor of the positive sperm retrieval. However the clinical examination of the patient remains important which can reveal some disorders in the genital tract (hypospadias, varicocele). Conversely the relevance of testicular atrophy is not dramatic for sperm extraction. But a special care should be for the sperm analysis, the way it is performed and mainly to search for a cryptozoospermia present in 15 to $20 \%$ of 
Table 1. Levels of extraction of spermatozoa obtained after surgery in relation with the type of azoopsermia and the histological aspect

\begin{tabular}{|l|c|c|c|}
\hline & $\begin{array}{c}\text { Increased } \\
\text { FSH: } \\
\text { secretory } \\
\text { azoospermia }\end{array}$ & $\begin{array}{c}\text { Increased FSH + } \\
\text { APLASIA and arrest } \\
\text { with normal FSH: } \\
\text { non obstructive } \\
\text { azoospermia }\end{array}$ & $\begin{array}{c}\text { Hypo- } \\
\text { spermatogenesis } \\
\text { with normal FSH } \\
\text { azoospermia }\end{array}$ \\
\hline $\begin{array}{l}\text { Number } \\
\text { of } \\
\text { patients }\end{array}$ & 427 & 484 & 174 \\
\hline Extraction & $\begin{array}{c}201 \\
(47 \%)\end{array}$ & $\begin{array}{c}223 \\
(46 \%)\end{array}$ & $\begin{array}{c}165 \\
(95 \%)\end{array}$ \\
\hline
\end{tabular}

Table 2. Levels of extraction of spermatozoa by the aetiology of azoospermia

\begin{tabular}{|l|c|c|c|}
\hline & $\begin{array}{c}\text { Number of } \\
\text { patients }\end{array}$ & $\begin{array}{c}\text { Number of } \\
\text { samples }\end{array}$ & $\begin{array}{c}\% \\
\text { extraction }\end{array}$ \\
\hline $\begin{array}{l}\text { Congenital absence of } \\
\text { vas deferens }\end{array}$ & $\begin{array}{c}118 \\
(14 \%)\end{array}$ & $\begin{array}{c}129 \\
(14 \%)\end{array}$ & $\begin{array}{c}126 \\
(98 \%)\end{array}$ \\
\hline $\begin{array}{l}\text { Obstructive } \\
\text { a7oospermia }\end{array}$ & $\begin{array}{c}219 \\
(26 \%)\end{array}$ & $\begin{array}{c}249 \\
(27 \%)\end{array}$ & $\begin{array}{c}222 \\
(89 \%)\end{array}$ \\
\hline $\begin{array}{l}\text { Fjaculatory } \\
\text { dysfunction }\end{array}$ & $\begin{array}{c}32 \\
(4 \%)\end{array}$ & $\begin{array}{c}34 \\
(4 \%)\end{array}$ & $\begin{array}{c}33 \\
(97 \%)\end{array}$ \\
\hline $\begin{array}{l}\text { Non obstructive } \\
\text { azoospermia }\end{array}$ & $\begin{array}{c}476 \\
(56 \%)\end{array}$ & $\begin{array}{c}494 \\
(55 \%)\end{array}$ & $\begin{array}{c}232 \\
(47 \%)\end{array}$ \\
\hline
\end{tabular}

patients with non-obstructive azoospermia [2]. The increased blood FSH levels is the main criteria of that pathology [5] with a mean value of $10 \mathrm{mIU} / \mathrm{ml}$ eventhough some authors suggest to consider lower FSH levels, and inhibin could help also as a predictive parameter for sperm retrieval [2]. In addition a testicular echogarphy should be realized in all these patients with non-obstructive azoospermia since numerous endogenous defects in the testicular tissue have been demonstrated [6]. The last parameters to consider are the caryotype and the genetic evaluation since the frequency of chromosomic disorders is increased in these patients. Nevertheless in the Klinefelter syndrome, the presence of spermatozoa has been demonstrated with a level of sperm extraction of more than $50 \%$; conversely, the $\mathrm{Y}$ microdeletions, especially in AZFa and AZFb regions, are a poor pronosotic value for sperm retieval $[2,13]$. In addition the age of the woman is also very important in the therapeutic strategy.

In 1993, Schoysman et al. were the first group to report a positive sperm extraction from testicular tissue to perform ICSI [11]. Nevertheless, from the various meta-analyses available (cochrane data-base) no clear methodology is recommended for sperm extraction $[4,7,9,16]$. The only parameter to keep in mind is the absence of clear informations concerning the
Table 3. Results obtained after ICSI with spermatozoa collected from surgery

\begin{tabular}{|l|c|c|c|c|}
\hline & $\begin{array}{c}\text { Normal } \\
\text { l'SII }\end{array}$ & $\begin{array}{c}\text { Increased } \\
\text { l'SII }\end{array}$ & $\begin{array}{c}\text { Non } \\
\text { obstructive } \\
\text { azoospermia }\end{array}$ & $\begin{array}{c}\text { Azoospermia and } \\
\text { cryptorchisdism }\end{array}$ \\
\hline Couples & 295 & 158 & 167 & 95 \\
\hline Cycles & 713 & 324 & 325 & 204 \\
\hline $\begin{array}{l}\text { Pregnancy/ } \\
\text { cycle }\end{array}$ & $\begin{array}{c}161 \\
(23 \%)\end{array}$ & $\begin{array}{c}51 \\
(16 \%)\end{array}$ & $\begin{array}{c}55 \\
(17 \%)\end{array}$ & $\begin{array}{c}39 \\
(19 \%)\end{array}$ \\
\hline $\begin{array}{l}\text { Delivery/ } \\
\text { cycle }\end{array}$ & $\begin{array}{c}125 \\
(18 \%)\end{array}$ & $\begin{array}{c}39 \\
(12 \%)\end{array}$ & $\begin{array}{c}43 \\
(13 \%)\end{array}$ & $\begin{array}{c}32 \\
(16 \%)\end{array}$ \\
\hline $\begin{array}{l}\text { Delivery/ } \\
\text { couple }\end{array}$ & $\begin{array}{c}147 \\
(50 \%)\end{array}$ & $\begin{array}{c}47 \\
(30 \%)\end{array}$ & $\begin{array}{c}47 \\
(28 \%)\end{array}$ & $\begin{array}{c}39 \\
(41 \%)\end{array}$ \\
\hline
\end{tabular}

Table 4. Results obtained after ICSI with spermatozoa collected from surgery in relation to the dates of collection. $1995-2003$ : First cycle of samples with fresh sperm, the second with frozen sperm; 2003 - 2007: First and second cycle of samples with frozen sperm

\begin{tabular}{|l|c|c|c|c|}
\hline & $\begin{array}{c}1995- \\
2003\end{array}$ & $\begin{array}{c}2003- \\
2007\end{array}$ & $\begin{array}{c}1995-2003 \\
\text { non obstructive } \\
\text { a7oospermia }\end{array}$ & $\begin{array}{c}2003-2007 \\
\text { non obstructive } \\
\text { a7.oospermia }\end{array}$ \\
\hline Couples & 268 & 192 & 90 & 77 \\
\hline Cycles & 437 & 288 & 140 & 104 \\
\hline $\begin{array}{l}\text { Pregnancy/ } \\
\text { cycle }\end{array}$ & $\begin{array}{c}87 \\
(20 \%)\end{array}$ & $\begin{array}{c}70 \\
(24 \%)\end{array}$ & $\begin{array}{c}19 \\
(14 \%)\end{array}$ & $\begin{array}{c}24 \\
(23 \%)\end{array}$ \\
\hline $\begin{array}{l}\text { Delivery/ } \\
\text { cycle }\end{array}$ & $\begin{array}{c}70 \\
(16 \%)\end{array}$ & $\begin{array}{c}55 \\
(19 \%)\end{array}$ & $\begin{array}{c}15 \\
(11 \%)\end{array}$ & $\begin{array}{c}19 \\
(18 \%)\end{array}$ \\
\hline $\begin{array}{l}\text { Delivery/ } \\
\text { couple }\end{array}$ & $\begin{array}{c}83 \\
(31 \%)\end{array}$ & $\begin{array}{c}60 \\
(31 \%)\end{array}$ & $\begin{array}{c}16 \\
(17 \%)\end{array}$ & $\begin{array}{c}19 \\
(25 \%)\end{array}$ \\
\hline
\end{tabular}

patients studied [13]. Whatever it seemed today that in a patient with a non-obstructive azoospermia a bilateral sampling, "gold standard" should be performed [13] and all discussions nowadays concerned the technical approach either classical testicular biopsy or a microdissection of testis tissue [2].

As a matter of fact, in case of non-obstructive azoospermia, with the extracted sperm used a delivery level/couple of $30 \%$ is expected whereas it is of $50 \%$ for patient with obstructive azoospermia [10] and its is generally accepted that frozen sperm is more successful than fresh sperm samples $[2,9]$ which is even more obvious in pateints with non-obstructivre azoospermia.

That approach with frozen samples is in addition very helpful since that avoid (one case of two) to stimulate the woman and to optimize the stimulatory protocol for the FIV/ICSI attempts. In our experience between 1995 and 2006, 1083 attempts ahev been performed with a pregancy rate per cycle of $21 \%, 16 \%$ of delivery/cycle i.e $36 \%$ delivery/couple, $42 \%$ with cry- 
Table 5. Results obtained after ICSI with spermatozoa collected from surgery in relation with the number of fertilized oocytes $(2$ PN)

\begin{tabular}{|l|c|c|c|c|}
\hline & $\begin{array}{c}<5 \\
2 \mathrm{PN} \\
\text { ocytes }\end{array}$ & $\begin{array}{c}\geq \mathrm{P} \\
2 \mathrm{PN} \\
\text { oocytes }\end{array}$ & $\begin{array}{c}<5 \\
\text { non } \\
\text { obstructive } \\
\text { azoospermia }\end{array}$ & $\begin{array}{c}\geq 5 \\
\text { non obstructive } \\
\text { azoospermia }\end{array}$ \\
\hline Couples & 311 & 125 & 120 & 38 \\
\hline Cycles & 684 & 264 & 218 & 68 \\
\hline $\begin{array}{l}\text { Pregnancy } \\
\text { cycle }\end{array}$ & $\begin{array}{c}117 \\
(17 \%)\end{array}$ & $\begin{array}{c}81 \\
(31 \%)\end{array}$ & $\begin{array}{c}29 \\
(13 \%)\end{array}$ & $\begin{array}{c}22 \\
(32 \%)\end{array}$ \\
\hline $\begin{array}{l}\text { Delivery/ } \\
\text { cycle }\end{array}$ & $\begin{array}{c}88 \\
(13 \%)\end{array}$ & $\begin{array}{c}65 \\
(25 \%)\end{array}$ & $\begin{array}{c}20 \\
(9 \%)\end{array}$ & $\begin{array}{c}20 \\
(30 \%)\end{array}$ \\
\hline $\begin{array}{l}\text { Delivery/ } \\
\text { couple }\end{array}$ & $\begin{array}{c}88 \\
(28 \%)\end{array}$ & $\begin{array}{c}65 \\
(52 \%)\end{array}$ & $\begin{array}{c}20 \\
(17 \%)\end{array}$ & $\begin{array}{c}20 \\
(52 \%)\end{array}$ \\
\hline
\end{tabular}

opreserved-thawed embryo included. More precisely we have recorded some variations between our data taking into account either normal or increased FSH in one hand and, between non-obstructive azoospemia versus cryptorchidism assocaited to non-obstructive azoospemia in an other hand, concerning the level of delivery/couple (Table 3).

For the non-obstructive azoospemia the level of pregnancy/couple was of $18 \%$ with frozen sperm whereas it was of $14 \%$ with fresh sample. If we compared the data collected in our FIV center (Table 4) we recorded a level of $14 \%$ of pregnancy/cycle during the first period (1995-2003) and 23\% for the second one (2003-2007) which corresponded to the used of frozen samples in the two cycles. In addition the amount of delivery/couple is higher in the second period ( 25 vs $8 \%$ ) compared to the first one (Table 4). The quality of the stimulation for the woman was also important since the level of pregancy/cycle was of $13 \%$ when there are less than 5 oocytes fertilized and that level reached $32 \%$ when 5 or more oocytes were fertilized (Table 5). The outcome of the pregnancies seemed to be slightly different for the sperm coming from patient with non-obstructive azoospermia compared to ejaculated sperm used in ICSI as suggested by Vernaeve et al. [15] who reported an increase of chromosomal and genital disorders.

Acknowledgements: I am pleased to thank Dr S Carreau for the English help.

\section{References}

[ 1] Anniballo R, Ubaldi F, Cobellis L, Sorrentino M, Rienzi L, Greco E, Tesarik J. Criteria predicting the absence of spermatozoa in the Sertoli cell-only syndrome can be used to improve success rates of sperm retrieval. Hum Reprod. 2000;15(11):2269-2277.

[2] Carpi A, Sabanegh E, Mechanick J. Controversies in the management of nonobstructive azoospermia. Fertil Steril. 2009;91(4):963-970.

[3] Devroey P, Nagy P, Tournaye H, Liu J, Silber S, Van Steirteghem A. Outcome of intracytoplasmic sperm injection with testicular spermatozoa in obstructive and non-obstructive azoospermia. Hum Reprod. 1996;11(5):1015-1018.

[4] Donoso P, Tournaye H, Devroey P. Which is the best sperm retrieval technique for non-obstructive azoospermia? A systematic review. Hum Reprod Update. 2007;13(6):539-549.

[5] Ezeh UI, Moore HD, Cooke ID. Correlation of testicular sperm extraction with morphological, biophysical and endocrine profiles in men with azoospermia due to primary gonadal failure. Hum Reprod. 1998;13(11):3066-3074.

[6] Haddad O, Leroy X, Lemaitre L, Biserte J, Rigot JM. Infertility and testicular tumour based on a series of 25 patients. Prog Urol. 2005;15(6):1096-1100.

[7] Harris SE, Sandlow JI. Sperm acquisition in nonobstructive azoospermia: what are the options? Urol Clin North Am. 2008;35(2):235-242.

[ 8] McLachlan RI, Rajpert-De Meyts E, Hoei-Hansen CE, de Kretser DM, Skakkebaek NE. Histological evaluation of the human testis - approaches to optimizing the clinical value of the assessment: mini review. Hum Reprod. 2007; 22(1):2-16.

[ 9] Nicopoullos JD, Gilling-Smith C, Almeida PA, Norman-Taylor J, Grace I, Ramsay JW. Use of surgical sperm retrieval in azoospermic men: a meta-analysis. Fertil Steril. 2004;82(3): 691-701.

[10] Osmanagaoglu K, Vernaeve V, Kolibianakis E, Tournaye H, Camus M, Van Steirteghem A, Devroey P. Cumulative delivery rates after ICSI treatment cycles with freshly retrieved testicular sperm: a 7-year follow-up study. Hum Reprod. 2003;18(9):1836-1840.

[11] Schoysman R, Vanderzwalmen P, Nijs M, Segal L, SegalBertin G, Geerts L, van Roosendaal E, Schoysman D. Pregnancy after fertilisation with human testicular spermatozoa. Lancet. 1993;342(8881):1237.

[12] Schulze W, Thoms F, Knuth UA. Testicular sperm extraction: comprehensive analysis with simultaneously performed histology in 1418 biopsies from 766 subfertile men. Hum Reprod. 1999;14(Suppl 1):82-96.

[13] Sharif K, Ghunaim S. Surgical sperm retrieval: what not to do. Fertil Steril. 2008;89(1):17-19.

[14] Van Peperstraten A, Proctor ML, Johnson NP, Philipson G. Techniques for surgical retrieval of sperm prior to intra-cytoplasmic sperm injection (ICSI) for azoospermia. Cochrane Database Syst Rev. 2008;(2):CD002807.

[15] Vernaeve V, Bonduelle M, Tournaye H, Camus M, Van Steirteghem A, Devroey P. Pregnancy outcome and neonatal data of children born after ICSI using testicular sperm in obstructive and non-obstructive azoospermia. Hum Reprod. 2003;18(10):2093-2097.

[16] Wald M, Makhlouf AA, Niederberger CS. Therapeutic testis biopsy for sperm retrieval. Curr Opin Urol. 2007;17(6): 431-438. 